\title{
MENUMBUHKAN RASA SOSIAL ANAK USIA DINI MELALUI BERMAIN DALAM KELOMPOK
}

\author{
Yuli Suhartini Nanik ${ }^{1}$, Ratno Abidin ${ }^{2}$, Naili Sa'ida ${ }^{3}$ \\ Mahasiswa Pendidikan Guru Pendidikan Anak Usia Dini FKIP \\ Universitas Muhammadiyah Surabaya
}

Email: yulisuhartini95@gmail.com, $\frac{\text { ratnoabidin@fkip.um-surabaya.ac.id, }}{\text { nailisaida@fkip.um-surabaya.ac.id }}$

\begin{abstract}
Abstrak: penelitian ini dilakukan pada peserta didik TK B TK'Aisyiyah Bustanul Athfal 6 Surabaya dengan menggunakan penelitian kuantitatif pre eksperimental design dengan model one group pre test-post test. Instrumen yang digunakan adalah berupa lembar observasi, tes (pre test-post test), wawancara dan dokumentasi. Data yang diambil melalui tehnik observasi pada saat proses kegiatan pembelajaran sebelum istirahat dengan memberikan perlakuan (treatmen) sebanyak lima kali. Untuk mengetahui kemampuan sosial peserta didik adalah melalui tes yang dilakukan sebelum dan sesudah perlakuan (treatmen). Hasil penelitian diperoleh pre test sebesar 17.0, post test sebesar 24.5. Analisis data menggunakan uji Wilcoxon dengan taraf kesalahan 5\% atau 0,05 dengan jumlah sampel 8 anak diperoleh nilai $\mathrm{T}$ hitung $=0, \mathrm{~T}$ tabel $=3$. Hal ini berarti ada pengaruh bermain dalam kelompok terhadap perkembangan kemampuan sosial anak usia dini di TK B TK 'Aisyiyah Bustanul Athfal 6 Surabaya. Terbukti anak mampu menerima pendapat teman dalam kelompok, anak mampu menerima hasil kerja teman dalam kelompok, anak mampu mengikuti kegiatan dengan teman dalam kelompok, anak mampu memecahkan masalah secara bersama-sama.
\end{abstract}

Kata kunci: Kemampuan sosial, anak usia dini.

Abstrack: the research was conducted on B Aisyiyah Bustanul Athfal 6 kindergarten students of Surabaya by using quantitative pre experimental research design with one group pre test-pos test. The instrument used is in form of piece of observation, test (pre test-pos test), interview and documentation. Man takes technique data through observation during the the process learning activities before break with give treatment five times. To understand the social students is through tests that were conducted before and after treatment. The result of research is the pre test is 17.0, post test is 24.5. The data analysis used The Wilcoxon test with an error rate 5\% or 0,05 with using sample 8 children so we can get the value Thitung $=0$, Ttabel $=3$. The maining is there was influece of playing in group to grow the social early childhood in TK B TK 'Aisyiyah Bustanul Athfal 6 Surabaya. The proved are the children are able to accept friend's opinion in grups, children are able to accept the works of frieds in groups, children are able to follow activities with friends in groups, children are able to solve the problem together.

Key words: Social skills, early childhood

\section{PENDAHULUAN}

Pengembangan aspek sosial merupakan hal yang sangat penting bagi anak usia dini karena hakekat manusia sebagai makhluk sosial, manusia dimanapun berada tidak dapat dipisahkan dari lingkungan masyarakatnya Sarwono, S. A (2014: 1). Menurut Anita Lie dalam Suprijono, A (2014: 56) bahwa tanpa interaksi sosial, tidak akan mungkin ada kehidupan bersama. Tetapi seiring bertambahnya kemajuan jaman, maka rasa sosial masyarakat semakin berkurang. Orang kebanyakan saling tidak perduli dengan yang lainnya, tidak saling kenal, semakin berkurangnya rasa empati, berkurangnya rasa memiliki satu sama lain, pupusnya saling 
bekerjasama dan gotong-royong. Apalagi di perkotaan dimana masyarakatnya sangat beragam dengan segala kesibukannya. Orang semakin sibuk dengan diri mereka sendiri apalagi ditunjang dengan adanya handphone, gagdet, ipad, dsb. Orang hanya memperdulikan komentar di media sosial tetapi kurang melihat \& perduli dengan lingkungan terdekatnya. Begitu juga yang akan terjadi pada anak-anak kita, mereka lebih suka main game dan gagdet atau melihat televisi yang sudah meracuni mereka sehingga mereka tidak memiliki kepekaan sosial (Kurniawan, H. 2016: 13).

\section{Perkembangan} sosial merupakan suatu proses pemerolehan kemampuan untuk berperilaku yang sesuai dengan keinginan yang berasal dari dalam diri seseorang dan sesuai dengan tuntutan dan harapan-harapan sosial yang berlaku di masyarakat (Gunarti, W., Suryani, L., \& Muis, A. 2014: 1.14). Dapat juga diartikan sebagai proses belajar untuk menyesuaikan diri terhadap normanorma kelompok, moral, dan tradisi, meleburkan yang saling berkomunikasi dan bekerjasama. Perkembangan sosial terjadi pada semua anak.

Perkembangan sosial adalah keadaan dimana seorang anak menyadari dan peduli pada identitas, hubungan dengan orang lain dan memahami lingkungan tempat tinggal dan masyarakatnya. Anak yang lemah belajar, mempunyai masalah dalam bergaul. Ketidakmatangan dan ketidakmampuan akan sangat berpotensi anak menjadi lebih sensitif, sehingga Interaksi sosial hendaklah selalu dalam pengawasan dan bimbingan yang cermat (Danar Santi, 2009: 15).
Dalam perkembangan sosial, setiap anak akan melalui sebuah proses panjang yang pada akhirnya nilai-nilai sosial tersebut menjadi bagian dalam diri seorang anak. Alur dari proses sosialisasi pada setiap individu dimulai sejak lahir sampai ia menjadi dewasa, menurut (Gunarti, W., Suryani, L., \& Muis, A. 2014: 1.15) adalah sebagai berikut:

\section{Proses Imitasi}

Berupa proses peniruan terhadap tingkah laku atau sikap serta cara pandang orang dewasa (model) dalam aktifitas yang dilihat anak secara sengaja belajar bergaul dari orang-orang terdekatnya (orang tua).

\section{Proses Identifikasi}

Berupa proses terjadinya pengaruh sosial pada seseorang atau dapat diartikan sebagai proses menyamakan tingkah laku sosial orang yang berada di sekitarnya sesuai dengan perannya kelak di masyarakat.

\section{Proses Internalisasi}

Berupa proses penanaman serta penyerapan nilai-nilai. Dengan kata lain, relatif mantap dan menetapnya suatu nilai-nilai sosial pada diri seseorang sehingga nilai-nilai tersebut tertanam dan menjadi milik orang tersebut.

Perilaku sosial anak berdasarkan tahapan usia perkembangan :

\section{Pasca lahir}

Anak lebih suka ditinggalkan tanpa diganggu. Merasa senang waktu berkontak erat dengan tubuh ibu. Menangis keras apabila merasa tidak enak., tetapi apabila didekap erat atau diayun dengan lembut akan berhenti menangis.

\section{Dua tahun sampai dua tahun setengah}


Mempunyai minat yang besar dalam hal mengumpulkan katakata. Mulai banyak bertanya dan bisa menunjukkan ciri dan sebagia anggota tubuh apabila ditanya. Senang mendapat persetujuan orang dewasa dan banyak bercakap-cakap.

6. Tiga tahun sampai lima tahun

Berbicara bebas pada dirinya sendiri, orang lain bahkan mainannya. Berbicara lancar, bermain dengan kelompok. Anak kadang merasa puas apabila bermain sendiri untuk waktu yang lama dan mulai menyenangi kisah seseorang/tokoh dalam film. Bentuk perilaku sosial yang berhasil tampak untuk penyesuaian sosial dan mulai berkembang dalam periode ini. Dalam periode ini memungkinkan anak tidak selalu berhasil dalam bergaul dengan teman-temannya. Pada periode ini merupakan tahap yang kritis karena pada masa ini dasar sikap sosial dan pola perilaku sosial dibentuk.

Bermain adalah serangkaian kegiatan atau aktifitas anak untuk bersenang-senang. Semua kegiatan anak yang ada unsur kesenangan dan kebahagiaan untuk anak usia dini serta menimbulkan kepuasan maka bisa dikatakan sebagai bermain. Dalam kamus Bahasa Indonesia disebutkan bahwa bermain berasal dari kata dasar main yang mempunyai arti melakukan kegiatan untuk menyenangkan hati. Jadi konteks bermain untuk anak usia dini adalah berbagai kegiatan dan aktivitas yang membuat anak menjadi senang, nyaman, ceria, bahagia dan bersemangat. Bermain dan permainan adalah merupakan satu kesatuan dan saling berkaitan yang dimaksud adalah dalam bermain selalu ada permainan dan para pemainnya. Ada beberapa alasan pentingnya bermain untuk anak usia dini:

1). Cara belajar anak yang paling efektif adalah melalui bermain

2). Dengan bermain anak dapat meningkatkan seluruh aspek perkembangannya yaitu dari norma agama dan moral, fisik motorik baik motorik halus maupun motorik kasar, bahasa, kognitif, sosial emosional, dan seni.

3). Bermain juga mengajarkan anak tentang keterampilan hidup, mengenal aturan, bersosialisasi, bekerjasama, disiplin.

Secara umum, bermain memiliki manfaat sebagai aktivitas menggerakkan badan, pelepasan energi, pengurangan ketegangan ekspresi diri, dan kesegaran fisik. Anak berkembang mulai dari kegiatan main yang dilakukan sendiri hingga bermain bersama. Bermain bersama atau bermain dalam kelompok dapat menumbuhkan kemampuan sosial anak, menurut Catron dan Allen (1999) dalam Musyfiroh dan Tatminingsih (2015: 1.24) bermain mendukung perkembangan sosialisasi dalam halhal

a. Interaksi sosial, dalam bermain adanya interaksi dengan teman sebaya dalam kelompok, orang dewasa dan memecahkan konflik.

b. Kerjasama, yaitu interaksi saling membantu, berbagi dan pola bergiliran.

c. Menghemat sumber daya, bermain dalam kelompok dapat saling menggunakan dan menjaga benda-benda dan lingkungan secara tepat.

d. Perduli terhadap orang lain, dapat memahami dan menerima perbedaan individu, memahami 
masalah menghargai teman.

multibudaya,

Bermain adalah sarana yang tepat untuk mengembangkan kemampuan bersosialisasi, berkomunikasi, dan memupuk kepercayaan diri. Tetapi dalam bermain juga menimbulkan resiko sosial (Musyfiroh dan Tatminingsih, 2015: 1.32-1.33), yaitu:

a. Bertengkar, dalam bermain selalu ditemukan adanya pertengkaran karena benturan kepentingan, keegoisan dan kebosanan. Orang dewasa atau pendidik hanya sebagai penengah saja agar anak dapat menyelesaikan masalah mereka sendiri.

b. Eksklusivitas, dalam bermain akan ditemukan anak-anak yang memilih teman tertentu untuk bermain bersama atau bermain berkelompok dan menolak teman lain yang tidak diinginkan. Pendidik dalam merecanakan strategi pembelajaran bermain dalam kelompok hendaknya membaurkan peserta didik untuk membentuk kelompok sehingga resiko eksklusivitas yang menimbulkan ada peserta didik yang lain yang akan menarik diri apabila tidak memiliki kelompok.

c. Minus sosialisasi, bermain individu menimbulkan keasyikan tersendiri karena anak tidak harus menunggu dan berbagi dengan teman yang lain. Anak yang demikian tidak akan mampu membangun affiliasi sosial. Pendidik hendaknya sering melibatkan peserta didik dalam kelompok dan mendorong anak untuk bermain bersama dengan temannya.

Adapun tujuan dari penelitian ini adalah: (1) Untuk mengetahui adanya pengaruh bermain dalam kelompok dalam menumbuhkan rasa sosial anak usia dini; (2) Untuk mendeskripsikan penerapan bermain kelompok dalam menumbuhkan rasa sosial anak usia dini.

\section{METODE PENELITIAN}

Penelitian ini menggunakan metode penelitian kuantitatif dengan disain pre eksperimetal yang menggunakan rancangan one group pre test-post test.

Desain penelitian

\begin{tabular}{|c|c|c|}
\hline Pre-test & $\begin{array}{c}\text { Variabel } \\
\text { terikat }\end{array}$ & Post-test \\
\hline $\mathrm{O} 1$ & $\mathrm{X}$ & $\mathrm{O} 2$ \\
\hline
\end{tabular}

Keterangan :

$\mathrm{X}$ : Perlakuan (treatmen) pembelajaran kooperatif

O1 : Perkembangan sosial dalam kemampuan bekerjasama

O2 : Perkembangan sosial dalam kemampuan bekerjasama yang diberikan perlakuan

Sampel dalam penelitian ini adalah kelompok B sebanyak 8 anak di TK 'Aisyiyah Bustanul Athfal 6 Surabaya yang beralamat di Jl.Mulyorejo no.100 Surabaya. Penelitian diadakan saat kegiata pembelajaran sebelum istirahat.

Tehnik pengumpulan data yang digunakan dalam penelitian ini adalah observasi partisipatif, wawacara dan dokumentasi. Observasi dilakukan dengan menggunakan catatan tertulis yang dilihat, didengar, dialami dan dipikirkan oleh peneliti. Sedangkan wawancara dilakukan oleh peneliti kepada guru kelas. Dokumentasi dalam bentuk pengambilan foto diambil saat pembelajaran berlangsung.

Tehnik analisis data menggunakan statistik non parametrik melalui uji Wilcoxon Match Pairs Test. Penelitian ini 
melibatkan TK B TK 'Aisyiyah Bustanul Athfal 6 Surabaya sebagai populasi dengan mengambil sampel sebanyak 8 anak. Perhitungan selisih akan menggunakan uji pre-test dan post-test untuk mengetahui adanya peningkatan.

\section{HASIL PENELITIAN}

Hasil penelitian menunjukkan bahwa kemampuan sosial anak meningkat pada setiap pertemuan yang diawali dengan pre-test dilanjutkan dengan pemberian perlakuan (treatmen) sebanyak lima kali dan yang terakhir adalah saat post-test. Pre-test sangat penting dilakukan pada penelitian pre eksperimental one group ini. Pre-test diberikan dan dilakukan untuk mengetahui seberapa besar kemampuan sosial anak pada awal pertemuan. Adapun hasil pre-test seperti dibawah ini:

Pemberian perlakuan (treatment) diharapkan dapat memberikan pengaruh terhadap peningkatan kemampuan sosial anak melalui kegiatan pembelajaran dalam bentuk bermain dalam kelompok yaitu ketika anak mendengar pendapat teman yang lain, perilaku anak pada saat ada teman yang sudah menyelesaikan tugasnya, ikut dalam kegiatan bersama dengan teman yang lain, dan bersama dengan teman untuk dapat menyelesaikan dan memecahkan masalah dalam kelompoknya yang dilakukan sebanyak lima kali. Dan hal ini dapat dibuktikan dari hasil post test.

\section{Hasil Post test}

\begin{tabular}{|c|c|c|c|c|c|c|c|}
\hline \multirow[t]{2}{*}{ No } & \multirow[t]{2}{*}{ Nama } & \multicolumn{4}{|c|}{$\begin{array}{l}\text { Indikator Perkembangan } \\
\text { sosial anak 5-6 th }\end{array}$} & \multirow[t]{2}{*}{$\begin{array}{l}\text { Jumla } \\
\text { h }\end{array}$} & \multirow[t]{2}{*}{$\begin{array}{l}\text { Rata- } \\
\text { rata }\end{array}$} \\
\hline & & $\mathrm{a}$ & $\mathrm{b}$ & $\mathrm{c}$ & $\mathrm{d}$ & & \\
\hline 1 & $\mathrm{Al}$ & 3 & 3 & 3 & 3 & 12 & 3 \\
\hline 2 & $\mathrm{Ak}$ & 3 & 3 & 3 & 3 & 12 & 3 \\
\hline 3 & B & 3 & 3 & 3 & 2 & 11 & 2.75 \\
\hline 4 & D & 3 & 3 & 4 & 4 & 14 & 3.5 \\
\hline 5 & $\mathrm{E}$ & 3 & 3 & 3 & 3 & 12 & 3 \\
\hline 6 & $\mathrm{Hf}$ & 3 & 3 & 4 & 3 & 13 & 3.25 \\
\hline 7 & $\mathrm{Hp}$ & 3 & 3 & 3 & 3 & 12 & 3 \\
\hline 8 & I & 3 & 3 & 3 & 3 & 12 & 3 \\
\hline & $\begin{array}{l}\text { Jumla } \\
\mathrm{h}\end{array}$ & 24 & 24 & 26 & 24 & 98 & 24.5 \\
\hline
\end{tabular}

\begin{tabular}{|c|c|c|c|c|c|c|c|c|c|c|c|c|c|c|c|}
\hline \multirow{4}{*}{$\begin{array}{l}\mathrm{N} \\
\mathrm{o}\end{array}$} & \multirow{4}{*}{ Nama } & \multirow{3}{*}{\multicolumn{4}{|c|}{$\begin{array}{c}\text { Indikator Perkembangan } \\
\text { sosial anak 5-6 th }\end{array}$}} & \multirow{4}{*}{$\begin{array}{c}\text { Juml } \\
\text { ah }\end{array}$} & \multirow{4}{*}{$\begin{array}{r}\text { Rata } \\
\text { rata }\end{array}$} & 6 & \multirow{2}{*}{$\begin{array}{l}\mathrm{Hf} \\
\mathrm{Hp}\end{array}$} & \multirow{2}{*}{$\frac{3}{3}$} & \multirow{2}{*}{3} & \multirow{2}{*}{$\begin{array}{l}4 \\
3\end{array}$} & \multirow{2}{*}{3} & \multirow{2}{*}{$\begin{array}{l}13 \\
12\end{array}$} & \multirow{2}{*}{$\begin{array}{l}3.25 \\
3\end{array}$} \\
\hline & & & & & & & & -7 & & & & & & & \\
\hline & & & & & & & & 8 & I & 3 & 3 & 3 & 3 & 12 & 3 \\
\hline & & A & $\mathrm{b}$ & $\mathrm{c}$ & $\mathrm{d}$ & & & & \multirow{2}{*}{$\begin{array}{l}\text { Jumla } \\
\mathrm{h}\end{array}$} & \multirow[t]{2}{*}{24} & \multirow[t]{2}{*}{24} & \multirow[t]{2}{*}{26} & \multirow[t]{2}{*}{24} & \multirow[t]{2}{*}{98} & \multirow[t]{2}{*}{24.5} \\
\hline 1 & $\mathrm{Al}$ & 2 & 2 & 2 & 3 & 9 & 2.25 & & & & & & & & \\
\hline 2 & $\mathrm{Ak}$ & 2 & 2 & 3 & 3 & 10 & 2.5 & & & & & & & & \\
\hline
\end{tabular}

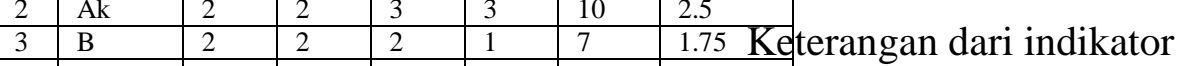

\begin{tabular}{|l|l|l|l|l|l|l|l}
3 & B & 2 & 2 & 2 & 1 & 7 & 2.75 \\
\hline 5 & E & 2 & 2 & 2 & 3 & 9 & 2.25
\end{tabular} perkembangan sosial anak 5-6 tahun

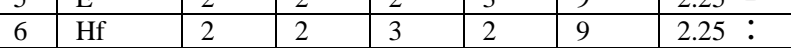

\begin{tabular}{lll|l|l|l|l|l|l}
7 & Hp & 2 & 2 & 2 & 2 & 8 & 2 \\
8 & I & 2 & 2 & 2 & 1 & 7 & 1.75
\end{tabular} a $=$ indikator menerima pendapat \begin{tabular}{l|l|l|l|l|l|l|l} 
Jumlah & 16 & 16 & 19 & 17 & 68 & 17.0
\end{tabular} teman dalam kelompok

$\mathrm{b}=$ indikator menerima hasil kerja

Keterangan dari indikator perkembangan sosial anak 5-6 tahun

$\mathrm{a}=$ indikator menerima pendapat teman dalam kelompok $\mathrm{b}=$ indikator menerima hasil kerja teman dalam kelompok $\mathrm{c}=$ indikator mengikuti kegiatan dengan teman dalam kelompok $\mathrm{d}=$ indikator memecahkan masalah dalam tugas teman dalam kelompok

$\mathrm{c}=$ indikator mengikuti kegiatan dengan teman dalam kelompok $\mathrm{d}=$ indikator memecahkan masalah dalam tugas

Dari hasil pre test dan post test menunjukkan bahwa ada pengaruh bermain dalam kelompok terhadap perkembangan kemampuan sosial anak setelah diberi perlakuan sebanyak lima kali. Pada awal perlakuan, kemampuan sosial anak 
masih rendah, perlakuan kedua belum ada perubahan, perlakuan ketiga sudah mulai ada perkembangan, memasuki perlakuan keempat anak sudah berkembang sesuai dengan yang diharapkan. Pada perlakuan kelima kemampuan sosial anak sudah berkembang dengan baik. Pada akhir penelitian diadakan post test dan hasil rata-rata kemampuan sosial peserta didik adalah 24.5.

Dalam penelitian ini menggunakan uji Wilcoxon Match Pairs Test untuk menguji hipotesis nihil (Ho) yang mengatakan tidak ada pengaruh pembelajaran kooperatif terhadap kemampuan sosial. Kriteria yang digunakan dalam menguji hipotesis nihil dalam penelitian adalah memakai taraf kesalahan 5\% atau 0,05 .

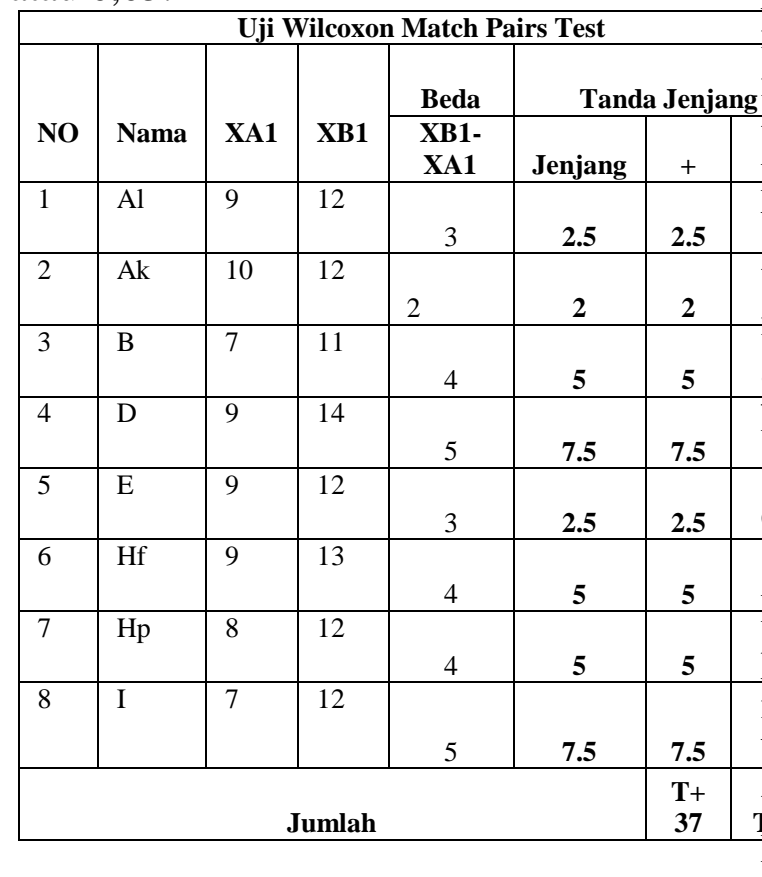

\section{PEMBAHASAN}

Pemberian

perlakuan

(treatment) diberikan pada kegiatan pembelajaran sebelum istirahat selama 5 hari berturut-turut. Pemberian perlakuan diberikan berturut-turut dengan harapan adanya peningkatan kemampuan sosial anak.
Pada awal perlakuan (treatmen), para peserta didik yang baru pertama kali mengenal kegiatan ini dengan mengerjakan tugas secara berkelompok, masih ditemukan ada anak yang kurang berkenan karena tidak kumpul dengan teman yang dia sukai, ada anak yang pasif atau diam saja, ada anak yang tidak mau menyelesaikan tugas sampai dengan selesai, dan ada anak yang tidak sepaham atau menolak hasil kerja temannya dan bahkan tidak menghargai hasil kerja teman secara verbal.

Pada pertemuan kedua saat pemberian perlakuan seperti pertemuan pertama yaitu pada kegiatan inti sebelum istirahat dan sebelum masuk kelas sentra. Pada pertemuan kedua ini peserta didik mulai paham bermain dan menyelesaikan tugas dalam kelompok tetapi masih ditemukan anak yang kurang nyaman dengan teman yang bukan teman akrabnya sehingga timbul rasa marah, yang pasif mulai mau membantu dan yang tidak setuju atau menolak dengan pendapat atau hasil kerja teman juga masih ada. o Pertemuan ketiga juga dilaksanakan pada kegiatan inti sebelum istirahat dan sebelum masuk kelas sentra. Dalam pemberi perlakuan yang ketiga ini anak mulai merasa senang dan nyaman bermain bekerjasama. Dalam treatmen yang ke tiga ini selain mengembangkan kemampuan sosial khususnya dalam bekerjasama juga mengembangkan aspek perkembangan lainnya yaitu aspek perkembangan motorik baik motorik kasar ketika anak berjalan melangkah dan menginjak bangun geometri dan motorik halus ketika anak memegang bangun geometri tanpa jatuh. Lalu aspek perkembangan bahasa juga 
berkembang ketika anak dapat menyebutkan bangun geometri yang diinjaknya dan mengembangkan aspek kognitif ketika anak mengerti bangun geometri yang disebutkannya, mengembangkan aspek norma agama ketika sebelum mulai permainan, anak harus berdoa terlebih dahulu seperti mengucapkan Basmalah. Perkembangan emosional juga meningkat ketika anak dapat menunggu dengan sabar operan bangun geometri dari temannya.

Pertemuan ke empat juga masih sama dilaksanakan pada kegiatan inti sebelum istirahat dan sebelum masuk kelas sentra. Peserta didik pada pertemuan ke empat ini diberikan perlakuan atau treatmen adalah peserta didik melipat bentuk geometri lalu menggunting dan menempelkannya pada sebuah kertas kosong sehingga membentuk sebuah gambar bunga matahari di dalam pot. Peserta didik sudah memahami dan dapat menyelesaikan tugasnya. Peserta didik sudah mulai menikmati menyelesaikan tugas dalam kelompok.

Pertemuan yang ke lima ini juga dilaksanakan pada kegiatan inti sebelum istirahat. Pada pertemuan yang kelima pemberian perlakuan atau treatmen ini membuat peserta didik menjadi lebih bersemangat bekerjasama karena terlihat dari adanya pembagian tugas dari kelompoknya dan peserta didik mulai menikmati bermain bersama teman yang lain dalam satu kelompok. Peserta didik semakin akrab dengan semua teman, saling menghargai hasil kerja teman, merasa bangga dengan hasil karya kelompoknya dan terutama tidak ada yang mengeluarkan kata-kata yang kurang pantas (kotor)atau tidak menghargai hasil karya teman secara verbal.
Semua anak sudah menikmati bermain bersama dalam kelompoknya.

Pada akhir pemberian perlakuan, diambil hasil post-test yang menunjukkan adanya peningkatan kemampuan sosial peserta didik yang dapat dilihat dari hasil post-test. Pada awal pre-test rata-rata kemampuan sosial anak usia dini 5-6 tahun adalah 17.0 dan pada saat post-test rata-rata kemampuan sosial anak menjadi 24.5. Hal ini dapat dibuktikan dengan perubahan perilaku anak yang berkembang sangat baik ketika peserta didik dapat menerima pendapat teman dalam kelompoknya, dapat menerima hasil kerja peserta didik yang lain dalam kelompoknya, dapat bermain bersama dan menyelesaikan tugas permainan bersama-sama.

\section{SIMPULAN}

Dari hasil awal penelitian (pre-test) menunjukkan nilai rata-rata pre-test kemampuan sosial anak usia dini 5-6 tahun adalah 17.0 dan nilai rata-rata post-test adalah 24.5. Setelah diaalisis dengan menggunakan uji Wilcoxon dengan taraf kesalahan 0,05 atau 5\% maka diperoleh nilai Thitung $=0$, Ttabel $=3$ sehingga nilai Thitung $<$ Ttabel. Hal ini membuktikan bahwa ada pengaruh bermain dalam kelompok terhadap perkembangan kemampuan anak usia dini 5-6 tahun di kelompok B TK'Aisyiyah Bustanul Athfal 6 Surabaya. Dan dapat dibuktikan dengan perubahan perilaku anak yang berkembang sangat baik ketika peserta didik dapat menerima pendapat teman dalam kelompoknya, dapat menerima hasil kerja peserta didik yang lain dalam kelompoknya, dapat bermain bersama dan menyelesaikan tugas permainan bersama-sama. 


\section{SARAN}

1. Guru, sebagai sesama pendidik anak usia dini hendaklah dalam setiap kegiatan pembelajaran diberikan dalam bentuk bermain dalam kelompok untuk meningkatkan kemampuan sosial peserta didik.

2. Lembaga, bermain dalam kelompok bisa dijadikan referensi pembelajaran untuk meningkatkan kualitas dan kuantitas peserta didik.

3. Peneliti yang lain, dapat dijadikan referensi dan diperbaiki segala kekurangan yang ada sehingga menjadi acuan referensi yang lebih baik lagi di masa yang akan datang.

\section{DAFTAR PUSTAKA}

Arifin, Z. (2009). Metodologi Penelitian Pendidikan. Surabaya: Lentera Cendekia.

Crow, L. D., \& Crow, A. (1958). Educational Psychology. New York USA: American Book Company. Diterjemahkan Anggota IKAPI. (1984) Psikologi Pendidikan. Surabaya: PT. Bina Ilmu..

Danar Santi, S.Psi. (2009). Pendidikan Anak Usia Dini. Indonesia: PT Macanan Cahaya Cemerlang.

Depdiknas. (2009). Peraturan Menteri Pendidikan Nasional Republik Indonesia Nomor 58 Tahun 2009 tentang Standar Pendidikan Anak Usia dini (tidak diterbitkan).

Gunarti, W., Suryani, L., \& Muis, A. (2014). Metode Pengembangan Perilaku dan Kemampuan Dasar Anak
Usia Dini. Tangerang Selatan: Universitas Terbuka.

Kurniawan, H. (2016). Sekolah Kreatif. Sekolah Kehidupan Yang Menyenangkan Untuk Anak. Yogyakarta: Ar-Ruzz Media

Musfiroh, T., \& Tatminingsih, S. (2015). Bermain dan Permainan Anak. Tangerang Selatan: Universitas Terbuka.

Sugiyono, Dr., Prof. (2015). Metode Penelitian Pendidikan. Pendekatan Kuantitatif, Kualitatif, dan $R \& D$. Bandung: Alfabeta.

Suprijono, A. (2014). Cooperative Learning. Teori dan Aplikasi PAIKEM. Yogyakarta: Pustaka Pelajar.

Suyadi, \& Maulidya. (2015). Konsep Dasar Paud. Bandung: PT Remaja Rosdakarya.

Zaman, B., \& Hernawan, A. H. (2014). Media dan Sumber Belajar PAUD. Tangerang Selatan: Universitas Terbuka. 
Yuli Suhartini Nanik ${ }^{1}$, Ratno Abidin ${ }^{2}$, Naili Sa'ida ${ }^{3}$ 